地盤工学ジャーナル Vol.15, No.3, 563-571

\title{
水銀およびふっ素によって污染された地盤の原位置不溶化処理に伴う 長期安定性に関する評価
}

\author{
日野良太 ${ }^{1}$, 三浦俊彦 ${ }^{1}$, 福武健一 ${ }^{1}$, 西田憲司 ${ }^{1}$, 森下智貴 ${ }^{1}$, 日笠山徹巳 ${ }^{1}$, 江種伸之 ${ }^{2}$ \\ 1 株式会社大林組 \\ 2 国立大学法人和歌山大学
}

\begin{abstract}
概 要
原位置不溶化処理を行った水銀およびふっ素で污染された地盤を対象として長期安定性を評価した。そこ で, (1)污染物質の溶出抑制効果の定量評価, (2)再溶出した污染物質の挙動把握が必要と考えた。ここでは, 前者について実際に原位置不溶化処理した地盤で採取した土を用い, 室内試験により不溶化処理土の再溶 出の可能性を確認した。後者は数值解析に基づき再溶出した物質の地盤内の挙動を検討した。その結果, 水銀は 130 年経過した場合に基準不適合となり, ふっ素は 1,800 年以上基準適合となることから不溶化処 理によって長期的に安定することが推察された。再溶出した污染物質は, 不溶化処理に伴う化学形態の恋 化と地盤の透水性低下に伴い, 水銀の場合に 100 年経過しても $0.02 \mathrm{~m}$ 程度の移動となった。以上のことよ り，原位置不溶化処理による長期的な拡大防止効果に関して定量的な評価が可能になった。

キーワード : 原位置不溶化処理, 室内試験, 数值解析, 水銀, ふっ素
\end{abstract}

\section{1. はじめに}

2003 年に土壌污染対策法（以下，法）が制定され，2010 年, 2017 年に大きな改正が行われた。法が制定された当初 は, 基準不適合土（以下, 污染土）を除去する手法として 掘削除去および場外搬出が主流であった1)。しかしながら， 法改正に従いリスク管理という観点が取り入れられたこ ともあり原位置処理手法や敷地外への特定有害物質の流 出防止策などの検討が増加してきた ${ }^{2)}$ 。

特定有害物質により污染された地盤において, 污染物質 の敷地外への拡大防止策の一つに原位置不溶化処理が挙 げられる ${ }^{3)}$ 。当処理は, 地盤内の污染土と薬剤を建設重機 によって混合攪挥4)するか井戸や裸孔等から薬剤を浸透さ せるものである ${ }^{5)}$ 。処理後の地盤内の污染物質は, 薬剤と の反応により地盤内で溶出および移動が抑制される。しか し, 時間経過や地盤内環境変化に伴う再溶出が懸念される。 これまでにも不溶化処理を行った地盤における特定有 害物質の再溶出に関連する研究は, いくつか実施されてい る。例えば, 王らは（一社）土壤環境センターでの検討と して不溶化処理土の一定期閒における安定性を評価する ために酸あるいはアルカリに懪された場合の室内試験方 法を提案している )。佐藤らは自然由来重金属等含有土の 不溶化処理土用いて, 雨水曝露 - 乾湿繰返しの促進試験に より重金属の溶出促進条件を検討している7)。

既往研究においては, 実現場で想定される環境条件を設
定し, 室内での促進試験による評価が主流となっている。 それゆえ不溶化処理土から再溶出した特定有害物質が地 盤内でどのような挙動を示すかを評価するためには, さら に検討が必要と考えられる。そこで, 筆者らは, 長期安定 性に関して, (1)污染物質の溶出抑制効果の定量評価, (2)再 溶出した污染物質の地盤内における挙動把握を実施した。 (1)に対しては, 実際に原位置不溶化処理した地盤から採取 した土を用いて, 各種室内試験により不溶化処理土の再溶 出リスクを確認した。(2)に対しては, 数值解析を用いて再 溶出した場合における污染物質の地盤内の挙動を検討し た。対象物質は, 実現場データが得られた水銀及びその化 合物 (以下，水銀）, ふっ素及びその化合物（以下，ふっ 素）とした。

\section{2. 不溶化処理方法}

不溶化処理は, 建設重機によって地盤内の污染土と薬剤 を混合攪拌した。施工イメージを図-1に示す。

不溶化処理を行うための薬剤選定は, 既往研究でいくつ か検討されている。例えば, 水銀に対して, 小嶋らは酸化 マグネシウムを添加することで難溶性の酸化物の生成を 報告している ${ }^{8)}$ 。小口は $\mathrm{Na}_{2} \mathrm{~S}$ と $\mathrm{FeSO}_{4}$ の添加により難溶 性の硫化物が生成すること, $\mathrm{FeSO}_{4}$ 量が多いほど不溶化効 果が大きいことを報告している9。一方，ふっ素に対して， 大山らは酸化マグネシウムを添加することで不溶化処理 


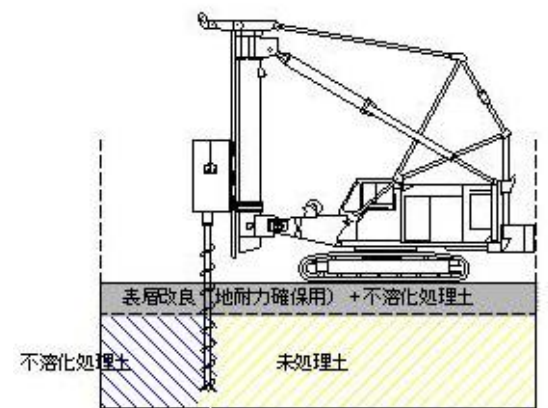

図-1 原位置不溶化処理 施エイメージ図

した事例を報告している ${ }^{10)}$ 。高橋らは鉄鋼スラグ含有ふっ 素に対してアパタイト処理を行い, フルオロアパタイトの 形成による鉱物学的不溶化を検討しており, カルシウムや リン酸の添加量が多いほどふつ素の溶出濃度が減少する ことを示した ${ }^{11)}$ 。亀井らは半水石亳に含まれるアルミナ, 酸化カルシウム, 硫酸カルシウムの水和反応で生成される エトリンガイトと高炉セメント B 種により不溶化処理を 行った ${ }^{12)}$ 。

本研究における水銀污染サイトでは，第二溶出量基準 $(0.005 \mathrm{mg} / \mathrm{L})$ 適合を目標として難溶性の硫化水銀に形態 変化および固化によって不溶化処理を行った ${ }^{13)}$ 。具体的に は, 污染土に対してチオ尿素 $\left(3.4 \mathrm{~kg} / \mathrm{m}^{3}\right)$ と高炉セメント B 種 $\left(136 \mathrm{~kg} / \mathrm{m}^{3}\right)$ を混合した。

一方, ふっ素污染サイトでは, 土壌溶出量基準 $(0.8 \mathrm{mg} / \mathrm{L})$ 適合を目標として難溶性のフッ化カルシウムに形態変化 および固化によって不溶化処理を行った ${ }^{14)}$ 。具体的には, 消石灰 $\left(102 \mathrm{~kg} / \mathrm{m}^{3}\right)$ と高炉セメント B 種 $\left(238 \mathrm{~kg} / \mathrm{m}^{3}\right)$ を混 合した。

\section{3. 不溶化処理土の再溶出特性調査}

\section{1 試験試料}

室内試験に使用した未処理土と不溶化処理土の試料の 性状を表-1 に示す。水銀污染サイトでは, 不溶化処理土と 未処理土, 污染源と見なされるガレキを採取した。ガレキ は, コンクリート様であり, 溶出量は $29 \mathrm{mg} / \mathrm{L}$ (環告 13 号), 含有量は $17,000 \mathrm{mg} / \mathrm{kg}$ (底質調査法) であった。試料は $0.5 \mathrm{~mm}$ 以上 $5 \mathrm{~mm}$ 以下に調整した。一方，ふっ素污染サイ トでは，不溶化処理土を採取した。

\section{2 室内試験方法}

\subsection{1振とう溶出試験}

不溶化処理土と地下水との液固比を変更した場合の短 期および長期的な溶出特性を把握した ${ }^{15)}$ 。振とう溶出試験 は, 液固比 $(\mathrm{L} / \mathrm{S})$ を $1,5,10,100$ とした。溶媒は, イオ ン交換水を使用した。振とう方法は，環告 18 号の振とう 回数を毎分 200 回，振とう幅を 4〜 $5 \mathrm{~cm}$ に調整した。振と う時間は，施工時における不溶化処理土が環告 18 号に準
表-1 土質及び初期性状

\begin{tabular}{|c|c|c|c|c|c|}
\hline & \multirow{3}{*}{ 項目 } & \multirow{3}{*}{ 単位 } & \multicolumn{3}{|c|}{ 値 } \\
\hline & & & 水銀 & 染サイト & ふっ素污染サイト \\
\hline & & & 未処理土 & 不溶化処理土 & 不溶化処理土 \\
\hline 土の & $0.075 \sim 2 \mathrm{~mm}$ & $\%$ & 37.5 & 44.4 & 65.9 \\
\hline 粒土 & $0.005 \sim 0.075 \mathrm{~mm}$ & $\%$ & 39.5 & 35 & 14.7 \\
\hline 分布 & 0.005mm未満 & $\%$ & 23 & 20.6 & 19.4 \\
\hline & の乾燥密度 & $\mathrm{g} / \mathrm{cm}^{3}$ & 1.67 & 1.16 & 0.96 \\
\hline & 透水係数 & $\mathrm{m} / \mathrm{s}$ & $3.0 \times 10^{-5}$ & $1.0 \times 10^{-9}$ & $5.2 \times 10^{-7}$ \\
\hline & 道効間隙率 & - & 0.2 & 0.09 & 0.14 \\
\hline 土鎄渷 & 出量(環告18号) & $\mathrm{mg} / \mathrm{L}$ & 29 & 0.0005 & 0.38 \\
\hline 土㙴合 & 有量(環告19号) & $\mathrm{mg} / \mathrm{kg}$ & 2,900 & 35 & 2,500 \\
\hline
\end{tabular}

拠した 6 時間で定量下限值未満であったため, 土壌溶出量 が定量下限值以上で検出されると考えて 48 時間とした。 溶出液（0.45 $\mu \mathrm{m}$ でろ過した溶液）の分析項目は，水銀濃 度，ふつ素濃度，pH である。

\subsection{2 通水溶出試験}

地下水が不溶化処理地盤内を透過することを考慮した 長期間の溶出量を把握した。通水溶出試験は, ISO/TS 21268-3 (Up-flow percolation test)に準拠して実施した（図2)。カラムは， $\phi 5 \mathrm{~cm} \times 30 \mathrm{~cm}$ として，5層ほぼ均等に分割 し, 各層で $125 \mathrm{~g}$ のランマーを高さ $20 \mathrm{~cm}$ から 3 回落下さ せることで不溶化処理土を締固めた。溶媒は，1 $\mathrm{mM}$ の $\mathrm{CaCl}_{2}$ 溶液を $0.25 \mathrm{~mL} / \mathrm{min}$ で通水した。浸出液は, ポアボリ ユーム（以下，PV） 0.1，0.5，1，5，10 で採水した。浸出 液 $(0.45 \mu \mathrm{m}$ でろ過した溶液）の分析項目は, 水銀濃度, ふっ素濃度， $\mathrm{pH}, \mathrm{EC}$ である。

\subsection{3拡散溶出試験}

地下水と土が接触している場合の溶出特性を把握した。 拡散溶出試験は，US EPA Method 1315 Compacted Granular Leach Test (CGLT)に準拠して実施した (図-3) ${ }^{16)}$ 。内径 $10 \mathrm{~cm}$ のアクリル製の容器に高さ $5 \mathrm{~cm}$ となるように試料を充填 し, 試料表面にナイロンネットおよびガラスビーズを厚さ $5 \mathrm{~mm}$ となるように敷き均一にした。イオン交換水を試料 上端から $9 \mathrm{~cm}$ の高さまで入れ, 20rpm で緩やかに攪拌を行 った。攪拌開始から 1，2，4，8，16，30，60，180 日後に 溶液を全て採取し, 同量のイオン交換水を入れた。溶出液 $(0.45 \mu \mathrm{m}$ でろ過した溶液) の分析項目は，水銀濃度，ふ つ素濃度，pH，ECである。

\subsection{4 逐次抽出試験}

污染土に含まれる水銀およびふっ素の化学形態を把握 するために逐次抽出試験を実施した。試験手順は, 図-4の とおりである 17), 18)。いずれの画分においても既往文献 ${ }^{18)}$ に則り液固比 10 で抽出を行い, 固液分離した溶液は 0.45 $\mu \mathrm{m}$ でろ過した後に水銀濃度とふっ素濃度を分析した。分 離後の固形分は, 次の画分で抽出するため溶媒に添加した。 水抽出態以外の抽出にあたって, $105^{\circ} \mathrm{C} て ゙$ 加熱乾燥させ 


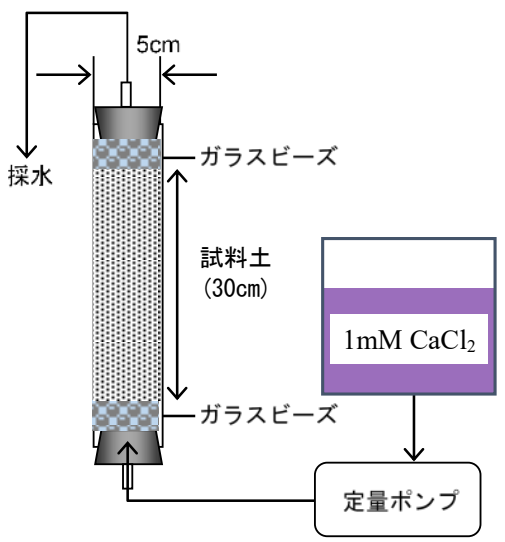

図-2 通水溶出試験装置概要

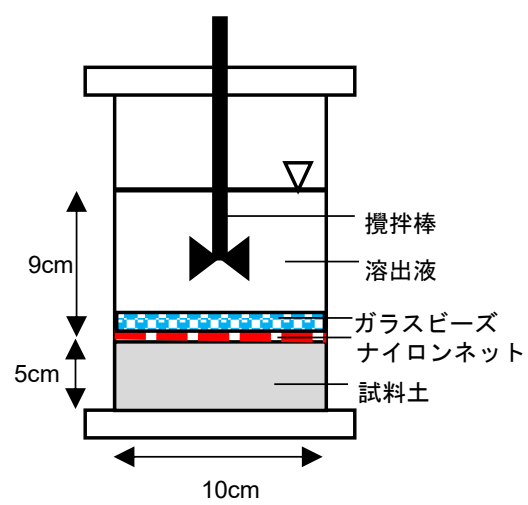

図-3 拡散溶出試験装置概要

る必要がある。ただし, 水銀污染土に対しては, 加熱に伴 う水銀の揮発が懸念されたため, 加熱を行わずにふっ素污 染土のみ加熱乾燥を行った。本試験は, 形態別の溶出特性 を把握するため, 溶出しない残椬画分を除いた水抽出態, 交換態, 酸抽出態 (無機物態十還元抽出態), 有機物態の 合計を $100 \%$ として整理した。

\section{3 室内試験結果}

\subsection{1 振とう溶出試験}

振とう溶出試験の結果を図-5 と図-6に示す。水銀につい ては, 未処理土を用いて同様の試験を行った。不溶化処理 土は, 水銀とふつ素のいずれも液固比を変更することで溶 出量が大きく増減せずに一定の化学平衡を示していた。一 方, 水銀の未処理土に関しては, 液固比 1 で $0.0079 \mathrm{mg} / \mathrm{L}$, 液固比 100 で $0.0021 \mathrm{mg} / \mathrm{L}$ となり, 液固比が大きくなるに つれて溶出量が減少した。これによって, 不溶化処理土が 水との液固比に影響せず溶出を抑制されており, 未処理土 は液固比が大きいほど溶出量が増加することが示された。 ここで, 既往文献 ${ }^{15)}$ は, 液固比が大きいほど長期的な溶出 挙動を示すと述べており, 本試験結果では不溶化処理土の 溶出量が液固比の変化で大きく増減しないことから長期 的な濃度増加の可能性は小さいことが示唆された。

水銀とふつ素の不溶化処理土は, いずれも $\mathrm{pH} 12$ 程度の 高アルカリ性を維持していた。水銀の未処理土は, $\mathrm{pH}$ 7 8 程度で大きな変動を示さなかった。

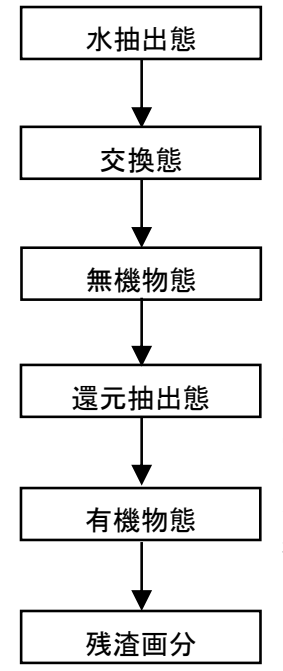

環告 18 号試験 水で 6 時間抽出

粘土粒子にイオン吸着している形態 $1 \mathrm{M}$ 酶酸アンモニウム溶液で 18 時間抽出 炭酸塩や粘土粒子に強く吸着している形態 $1 \mathrm{M}$ 酶酸ナトリウムで 18 時間抽出

非晶質の酸化鉄等と結合している形態

$0.2 M$ 塩酸ヒドロキシルアミンで 18 時間抽出

有機物と結合している形態 過酸化水素処理後

1. 78M 酶酸ナトリウム溶液で 30 分抽出

底質調査方法で全含有量分析

図-4 逐次抽出試験の手順

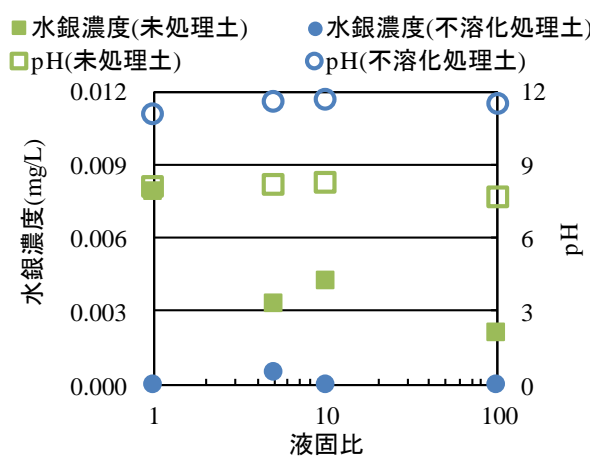

図-5 振とう溶出試験結果 (水銀)

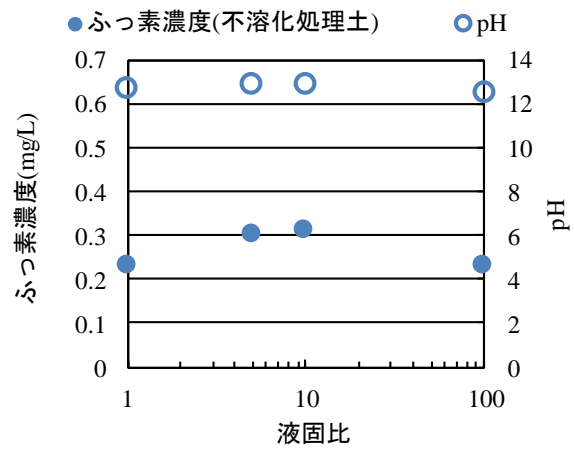

図-6 振とう溶出試験結果 (ふつ素)

\subsection{2 通水溶出試験}

不溶化処理土を使用した通水溶出試験の結果を図-7 か ら図-10 に示す。水銀については, 通水を開始してから PV0.5 から 1 の間で上昇し始め, $0.0005 \mathrm{mg} / \mathrm{L}$ を超過してお り，EC は継続的に低下した。一方，ふっ素については， 通水を開始してから PV0.1 で今回試験の最大值を示した 後に低下し，PV 5，10 で概ね横ばいとなった。なお，PV 10 の通水量では，ふっ素濃度の基準不適合は認められず に EC は高い值を維持していた。また，水銀とふっ素のい ずれにおいても $\mathrm{pH}$ の変動は少なく，水銀およびふっ素の いずれも $\mathrm{pH} 10.7$ 以上とアルカリ条件を維持していた。ア ルカリ条件の維持は, 不溶化処理を行うためにセメント系 の材料を添加したためである。本試験により，不溶化処理 を行うことでふっ素は長期的にも低下傾向を示すことを 


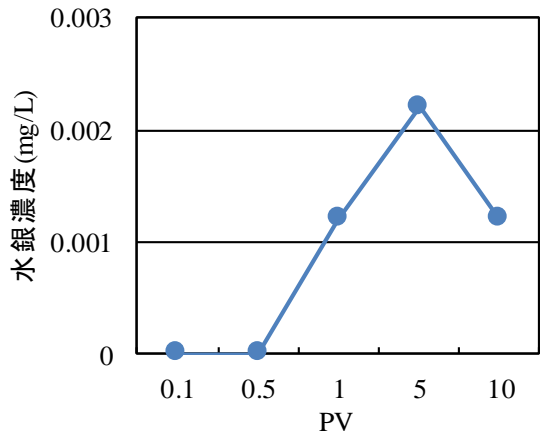

図-7 通水溶出試験結果 (水銀污染土 水銀濃度)

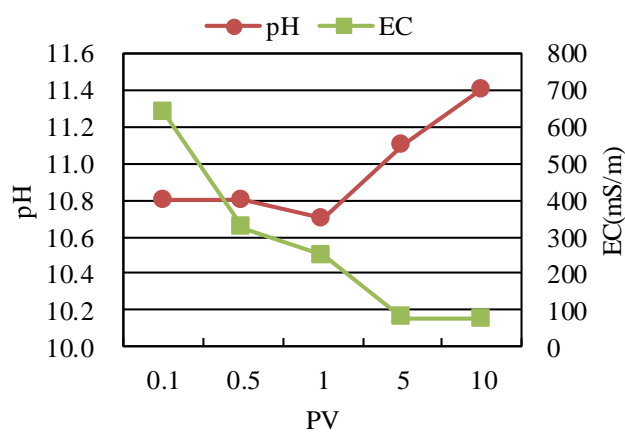

図-8 通水溶出試験結果 (水銀污染土 pH, EC)

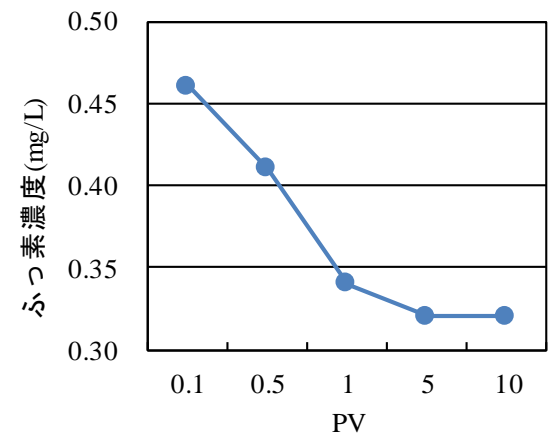

図-9 通水溶出試験結果 (ふつ素污染土 ふつ素濃度)

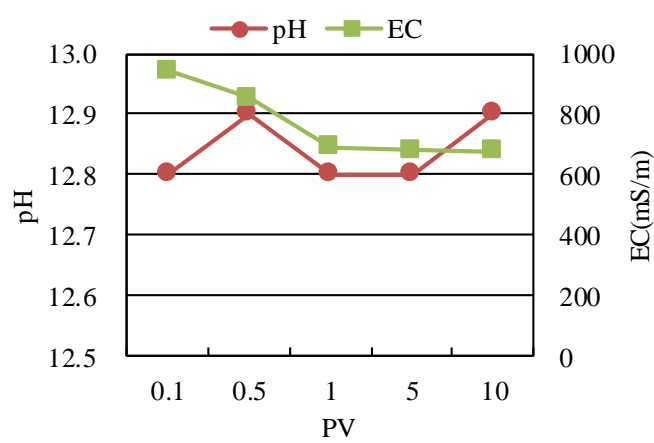

図-10 通水溶出試験結果 (ふつ素污染土 pH，EC)

確認した。一方，水銀は $0.0005 \mathrm{mg} / \mathrm{L}$ を超過しているが， 当サイトで不溶化処理の目標とした $0.005 \mathrm{mg} / \mathrm{L}$ 未満の低濃 度を維持することを確認した。そのため, 水銀は長期間の 通水に伴い土に含まれる難溶性の形態が水溶性に変化し たことにより溶出が増加したと考えられる。一方, ふっ素 は試験開始時に水溶性の形態が溶出し, 通水に伴い難溶性 の形態が溶出を抑制できたと考えられる。

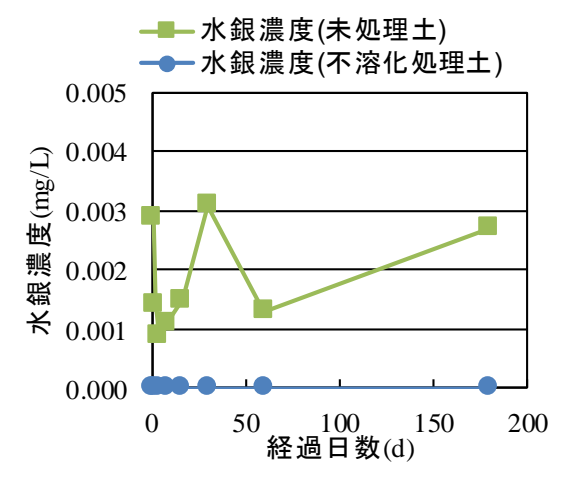

図-11 拡散溶出試験結果 (水銀污染土 水銀濃度)

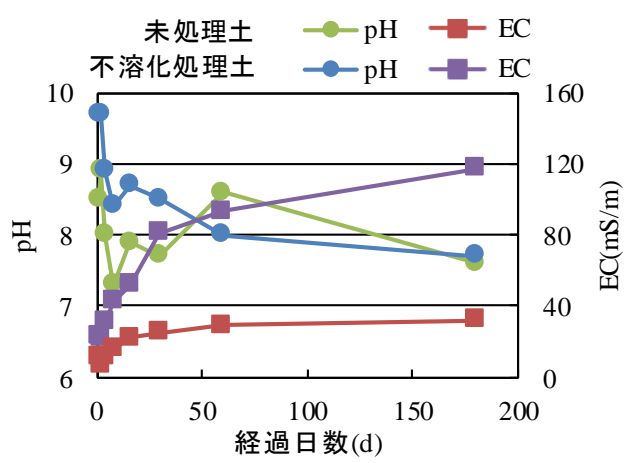

図-12 拡散溶出試験結果(水銀污染土 pH, EC)

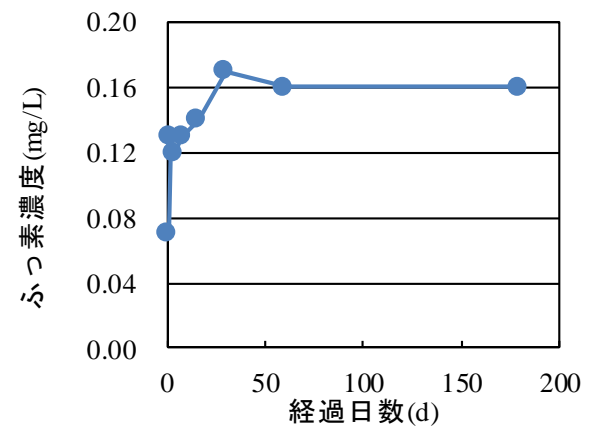

図-13 拡散溶出試験結果(ふっ素污染土 ふっ素濃度)

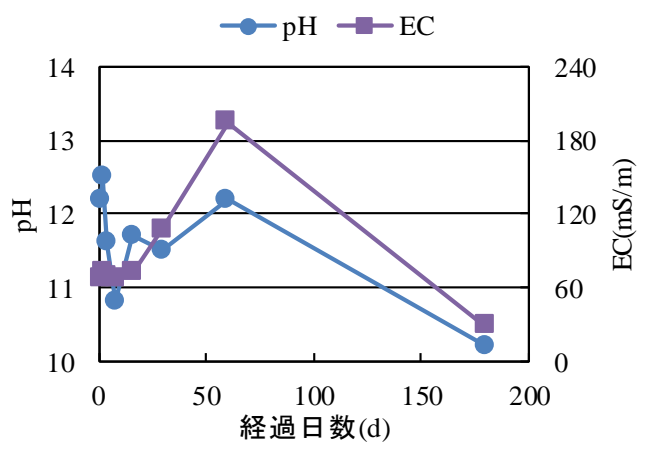

図-14 拡散溶出試験結果 (ふっ素污染土 pH，EC)

\subsection{3 拡散溶出試験}

拡散溶出試験の結果を図-11 から図-14 に示す。水銀につ いては, 振とう溶出試験と同様に未処理土も用いて試験を 行った。水銀の不溶化処理土は試験期間中に定量下限值 $(0.0005 \mathrm{mg} / \mathrm{L})$ 以上とならなかった。一方, 水銀の未処理 土とふつ素の不溶化処理土は, 試験期間中に多少の濃度変 化を確認しながらも継続的に溶出し続けた。そのため，水 


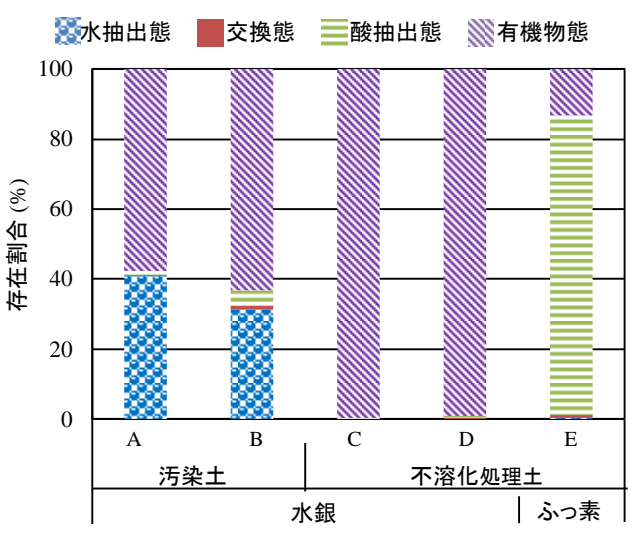

図-15 逐次抽出試験結果

と接触のみしている場合に不溶化処理土は, 通水試験と異 なり溶出量を長期間抑制できた。一方, 未処理土は水と接 触することで継続的に溶出することが確認できた。不溶化 処理土の $\mathrm{pH}$ と $\mathrm{EC}$ について, $\mathrm{pH}$ は, 時閒経過とともに減 少しており, 水銀が $\mathrm{pH} 10$ から $\mathrm{pH} 8$ 程度, ふっ素が $\mathrm{pH} 12$ から $\mathrm{pH} 10$ 程度となった。 $\mathrm{EC}$ は, 水銀が継続的に増加し, ふっ素は 60 日まで増加し, いずれも 30〜200 $\mathrm{mS} / \mathrm{m}$ 程度と なった。一方, 水銀の未処理土の $\mathrm{pH}$ と $\mathrm{EC}$ にいて, $\mathrm{pH}$ は, 時間変化とともに減少しており, pH9 から pH8 程度と なった。EC は, 不溶化処理土と同様に試験開始 60 日まで は増加しており, $40 \mathrm{mS} / \mathrm{m}$ 程度で横ばいとなった。試験開 始 180 日後のふつ素の不溶化処理土の $\mathrm{EC}$ の急減及び $\mathrm{pH}$ の低下について, 本試験は分析の度に溶液を新たな水と入 れ替える。そのため, 試験期間中（180日）に水と接触す る試料土の表面からセメント成分が溶出したと想定され るが, 水銀及びろっ素の溶出量は低い状態を維持していた。

\subsection{4逐次抽出試験}

逐次抽出試験の水銀とふつ素の結果を図-15 に示す。試 験に使用した污染土は，水銀が不溶化処理前（図中：A， B）と不溶化処理後 (図中: C, D), ふつ素が不溶化処理後 （図中：E）である。不溶化処理は, 水抽出態と交換態を 有機物態や酸抽出態へ変化することで濃度低減を行う。

水銀の不溶化処理土は, 水抽出態が $0.1 \%$, 交換態が $0.2 \%$, 酸抽出態が $0.7 \%$, 有機物態が $99 \%$ となり, 溶出の小さい 有機物態が大部分を占めていた。

一方, ふっ素の不溶化処理土は, 水抽出態が $0.2 \%$, 交換 態が $1.0 \%$, 酸抽出態が $85.5 \%$, 有機物態が $13.3 \%$ となり, 炭酸塩や非晶質の酸化鉄等と結合している無機物態と還 元抽出態が大部分を占めていた。すなわち, 水銀とふっ素 のいずれにおいても, 溶出する可能性のある形態の水抽出 態と交換態が大きく減少したと考えられる。

\subsection{5 室内試験結果の考察}

いずれの室内試験においても不溶化処理を行うことに よって, 水銀およびふっ素の溶出を抑制できることを確認 した。今回は，污染土に含まれる污染物質の絶対量の検討
を行っていない。しかし，逐次抽出試験の結果より不溶化 処理土の潜在可能溶出量 (絶対量) は少ないと考えられる。

振とう溶出試験によって, 不溶化処理土及び未処理土の 液固比による溶出量の変化を確認した。その結果, 不溶化 処理土に含まれるセメント成分の残留に加えて化学的に 難溶性に形態変化することで不溶化処理の効果を長期的 に維持していることも推察された。

通水溶出試験によって, 水銀についてはPV0.5（通水量 $420 \mathrm{~mL}$ ）を通水することで水銀が溶出しており，ふっ素に ついてはPV 10 (通水量 9,600mL) 以上を通水した場合で も基準值 $(0.8 \mathrm{mg} / \mathrm{L})$ を超過することはなかった。室内試験 の結果を用いて実現場で再溶出するまでの年数を換算す る場合, 室内試験で物質が溶出した通水量を実現場の地下 水が室内試験で使用したカラム面積を通過する場合の地 下水流量 $3.2 \mathrm{~mL} / \mathrm{y}$ で除すことによって算出可能である。水 銀については 130 年後に溶出するおそれがあり, ふつ素に ついては 1,800 年以上基準適合であることが示唆された。

拡散溶出試験では, 強制的に振とうや通水する振とう溶 出試験や通水溶出試験に比べて土を乱す行為が小さいた め両試験と比較して不溶化処理土の溶出量が抑制された。 さらに, 未処理土は継続的に溶出されたことから不溶化処 理による溶出量の抑制効果を確認できた。

以上のことより, 不溶化処理土は, 未処理土に比べて溶 出量を低減できることに加えて, 長期的にも安定した状態 であると推察された。しかしながら, 少量の再溶出は懸念 されることから, 再溶出した污染物質の地盤内での移動状 態を定量的に把握するために通水溶出試験で得られた不 溶化処理土の最大濃度を用いて数值解析を実施した。

\section{4. 不溶化処理土における重金属等の挙動解析}

\section{1 数值解析手法}

数值解析は, 水平二次元の Domenico 式 ${ }^{19)}$ (式(1), 式(2)) に基づいた。

$$
\begin{gathered}
C(x, 0, t)=\left\{\frac{1}{2} \exp \left[\frac{x}{2 \alpha_{x}}\left(1-\sqrt{1+\frac{4 \times \lambda \times \alpha_{x}}{v}}\right)\right]\right\} \times \\
\left\{\operatorname{erfc}\left[\frac{1}{2 \sqrt{\alpha_{x} \times v / R \times t}}\left(x-\frac{v \times t}{R} \sqrt{1+\frac{4 \times R \times \alpha_{x}}{v}}\right)\right]\right\} \times\left\{\operatorname{erf}\left(\frac{S_{w}}{4 \sqrt{\alpha_{y} \times x}}\right)\right\} \times C \\
R=1+\frac{\rho_{d}}{n_{e}} \times K_{d}
\end{gathered}
$$

入力パラメータを表- 2 に示す。今回の解析で用いた入力 パラメータの内, 污染源地下水濃度は前章の室内試験（通 水溶出試験）で得られた最大值を適用し，分配係数は 4.2 項で示す吸着試験に基づく算出結果を用いた。動水勾配は, 地盤条件から設定し, 透水係数 (JIS A 1218), 帯水層の有 効間隙率 (加圧板処理-実容積法), 土の乾燥密度 (JIS A 1210) は実現場の採取土を用いた土質試験の結果を使用した。た だし，ふつ素污染サイトの不溶化処理前における帯水層の 有効間隙率と土の乾燥密度は, 地盤条件が類似している水 銀污染サイトと同様の值を使用した。分散長は, 距離の 1/10〜1/100 に設定した ${ }^{20)}$ 。今回の数值解析の概念モデル 


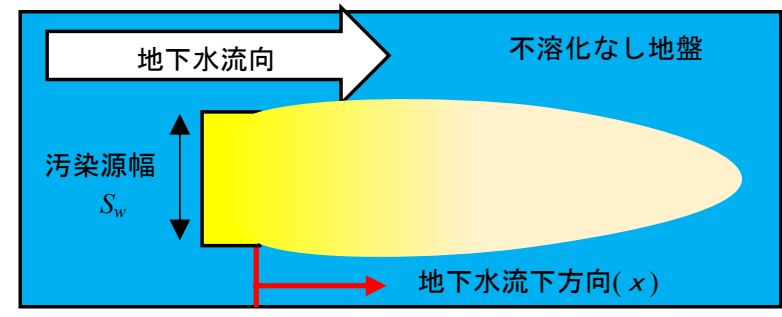

図-16 モデル概念図 (不溶化処理なし)

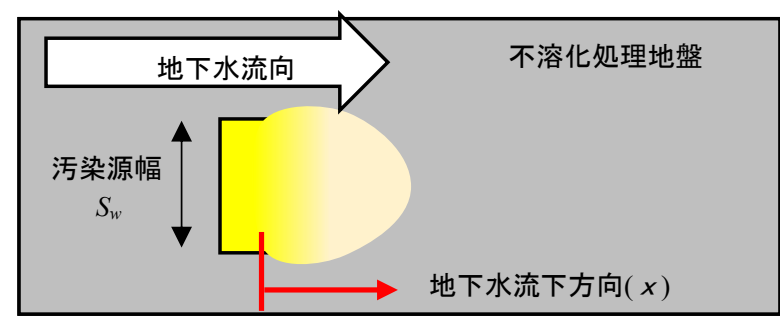

図-17 モデル概念図 (不溶化処理あり)

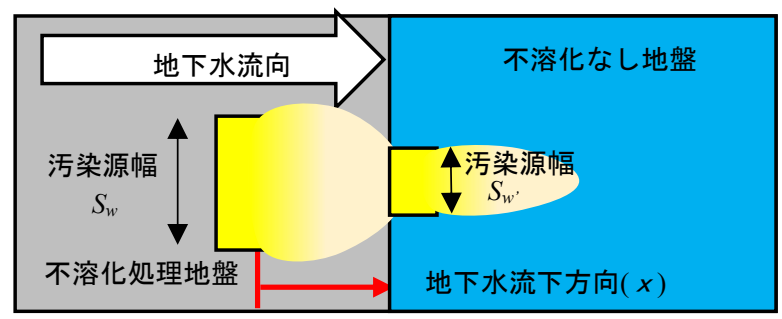

図-18 モデル概念図(不溶化処理有無の境界)

を図-16 から図-18 に示す。数值解析は, 環境省の地下水污 染が到達し得る距離の計算ツール 21)の評価年数と同様に 100 年後の $x$ 軸方向（地下水流向）の濃度分布状況を把握 するために次の条件を設定した。

1) 一定の污染源幅を持つ污染源から地下水流向に沿って 污染物質が移動する。

2) 污染物質の評価地点までの距離 $(X)$ は, 4.3 項で算出 した 100 年後に水銀が基準值未満となる最大距離の $185 \mathrm{~m}$ 地点であったことから 200m に設定した。

3) 污染源濃度は減少しない。

4) 不溶化処理のセメント混合により, 地盤の透水性が $1 \times$ $10^{-5} \mathrm{~m} / \mathrm{s}$ から $1 \times 10^{-9} \sim 10^{-7} \mathrm{~m} / \mathrm{s}$ 程度まで低下寸る。さら に, 化学形態変化により吸着性が異なると想定される。

5) 不溶化処理地盤の污染源（図-17 中の污染源幅）は，処 理前に高濃度であった局所的な範囲で，長期閒経過に 伴い污染物質が再溶出した場合を想定し, それ以外の 範囲の地盤には污染がなく, 再溶出もないものとする。

6) 不溶化なし地盤の污染源は, 5)に記載の条件と同じもの とし，それ以外の範囲にある地盤は污染がないものと
する。

7) 不溶化処理地盤から不溶化なし地盤の污染物質が移動 する場合，不溶化なし地盤の污染源（図-18中の污染源 幅 $\left.\left(S w^{\prime}\right)\right)$ は, 4.3 項で算出した不溶化処理地盤の污染 物質が基準值（水銀：0.0005mg/L） か目標值（ふつ素 : $0.08 \mathrm{mg} / \mathrm{L}$ ) となった污染源からの距離（水銀 : $0.02 \mathrm{~m}$, ふっ素: $3.3 \mathrm{~m}$ ) で $5 \mathrm{~m}$ とした。なお, $5 \mathrm{~m}$ の污染源幅は, 数值解析を行う上での想定条件として，ふつ素の目標 值は，初期濃度が基準適合であるため基準值の $1 / 10$

$(0.08 \mathrm{mg} / \mathrm{L})$ 未満を目標值と設定した。

8) 不溶化処理地盤から不溶化なし地盤の污染物質が移動 する場合は，不溶化処理によって污染物質が化学的に 形態変化していると想定される。そこで, 分配係数は, 不溶化処理土の溶出液に対して山砂を吸着した場合の 值を使用する。

\section{2 吸着パラメータの取得}

\subsection{1 室内試験方法}

山砂と不溶化処理土に対して化学形態が異なる溶液の 吸着特性を把握した。試験は, 液固比 $(\mathrm{L} / \mathrm{S})$ を $1,5,10$, 100 として 24 時間振とうを行った。試験に使用した溶液 は, 試薬を用いて所定の濃度に調整するか溶出液を用いた。 試薬 (水銀: 金属水銀, 䣷酸フェニル水銀, 硝酸水銀 (II), ふっ素 : フッ化カルシウム, フッ化マグネシウム, フッ化 アルミニウム）を用いた溶液は，水銀濃度を 0.03 $0.05 \mathrm{mg} / \mathrm{L}$ 程度，ふつ素濃度を $5 \mathrm{mg} / \mathrm{L}$ 程度に調整した。溶 出液（污染源と見なされるガレキの溶出液, 不溶化処理土 の溶出液）は，溶媒（イオン交換水）を用いて液固比を 1 か 5 に設定し, 48 時間振とうして $0.45 \mu \mathrm{m}$ でろ過した。 試験では, 山砂と不溶化処理土に吸着した後の溶液の平衡 濃度を測定した。山砂は, 透水性が高い砂質系の地盤にお ける污染物質の吸着特性を把握するために使用した。

\subsection{2 室内試験結果}

吸着試験により作成した吸着等温線を図-19 と図-20 に 示す。吸着等温線を基にして, 図中赤丸の液固比 5 の平衡 濃度と吸着量を用いてヘンリー型吸着等温式により計算 した分配係数を表-3に示す。化合物の種類によって土との 吸着性が異なり，山砂の場合は，水銀とふっ素のそれぞれ

表-2 数值解析入カパラメータ

\begin{tabular}{|c|c|c|c|c|c|c|c|c|c|c|}
\hline \multirow{3}{*}{ 記号 } & \multirow{3}{*}{ 名称 } & \multirow{3}{*}{ 単位 } & \multirow{3}{*}{ 值 } & \multirow{3}{*}{ 記号 } & \multirow{3}{*}{ 名称 } & \multirow{3}{*}{ 単位 } & \multicolumn{4}{|c|}{ 值 } \\
\hline & & & & & & & \multicolumn{2}{|c|}{ 水銀污染サイト } & \multicolumn{2}{|c|}{ ふっ素污染サイト } \\
\hline & & & & & & & 不溶化処理前 & 不溶化処理後 & 不溶化処理前 & 不溶化処理後 \\
\hline$t$ & 経過時間 & $\mathrm{y}$ & 100 & C & 污染源地下水濃度 & $\mathrm{mg} / \mathrm{L}$ & 29 & 0.002 & 15 & 0.46 \\
\hline$X$ & 評価地点までの距離 & $\mathrm{m}$ & 200 & $k$ & 透水係数 & $\mathrm{m} / \mathrm{s}$ & $3 \times 10^{-5}$ & $1 \times 10^{-9}$ & $1.2 \times 10^{-5}$ & $5.2 \times 10^{-7}$ \\
\hline$S_{w}$ & 污染源幅 & $\mathrm{m}$ & 10 & $n_{e}$ & 帯水層の有効間隙率 & - & 0.2 & 0.09 & 0.2 & 0.14 \\
\hline$\alpha_{x}$ & $x$ 方向の分散長 & $\mathrm{m}$ & $0.1 \times x$ & $\rho_{d}$ & 土の乾燥密度 & $\mathrm{g} / \mathrm{cm}^{3}$ & 1.67 & 1.16 & 1.67 & 0.96 \\
\hline$\alpha_{y}$ & $y$ 方向の分散長 & $\mathrm{m}$ & $0.01 \times x$ & $K_{d}$ & 土㙴-水分配係数 & $\mathrm{cm}^{3}-\mathrm{H}_{2} \mathrm{O} / \mathrm{g}$-soil & \multicolumn{4}{|c|}{ 表-3参照 } \\
\hline$i$ & 動水勾配 & $\mathrm{m} / \mathrm{m}$ & 0.005 & $v$ & 地下水流速 & $\mathrm{m} / \mathrm{y}$ & \multicolumn{4}{|c|}{$k \times i / n_{e}$} \\
\hline$\lambda$ & 一次分解定数 & $1 / \mathrm{y}$ & 1 & & & & & & & \\
\hline
\end{tabular}




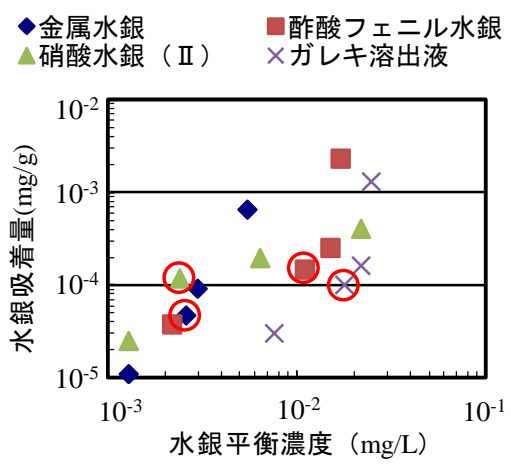

図-19 吸着試験結果 (水銀) 図中赤丸は液固比 5 の結果

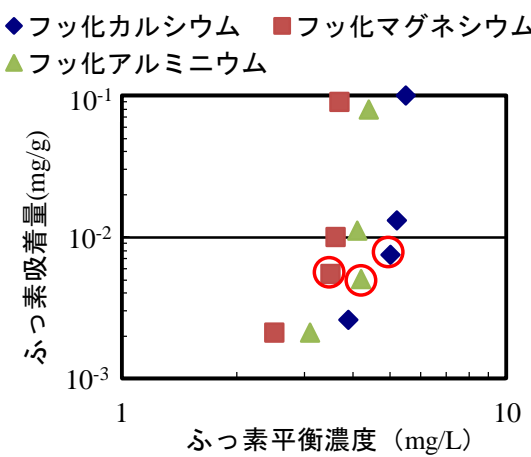

図-20 吸着試験結果 (ふつ素) 図中赤丸は液固比 5 の結果

表-3 吸着試験に基づく分配係数算出結果

\begin{tabular}{|c|c|c|c|}
\hline \multirow{4}{*}{ 物質 } & \multirow{2}{*}{ 溶液 } & \multicolumn{2}{|c|}{ 分配係数 $\left(K_{d}\right) \mathrm{cm}^{3}-\mathrm{H}_{2} \mathrm{O} / \mathrm{g}$-soil } \\
\cline { 3 - 4 } & & \multicolumn{2}{|c|}{ 吸着士 } \\
\cline { 3 - 4 } & & 山砂 & 不溶化処理土 \\
\hline \multirow{4}{*}{ 水銀 } & 金属水銀 & 18.1 & - \\
\cline { 2 - 4 } & 酢酸フェニル水銀 & 13.2 & - \\
\cline { 2 - 4 } & 硝酸水銀 $($ II $)$ & 49.2 & - \\
\cline { 2 - 4 } & ガレキ溶出液 & 5.6 & - \\
\cline { 2 - 4 } & 不溶化処理土溶出液 & 18.3 & - \\
\hline \multirow{4}{*}{ ふっ素 } & フッ化カルシウム & 1.5 & - \\
\cline { 2 - 4 } & フッ化マグネシウム & 1.6 & 0.7 \\
\cline { 2 - 4 } & フッ化アルミニウム & 1.2 & - \\
\cline { 2 - 4 } & 不溶化処理土溶出液 & 3.1 & \multicolumn{2}{|c|}{} \\
\hline
\end{tabular}

において, 硝酸水銀 $($ II $)>$ 金属水銀 $>$ 酢酸フェニル水銀>ガ レキ溶出液, フッ化マグネシウム>フッ化カルシウム>フッ 化アルミニウムであった。また，図には示していないが， 不溶化処理土の溶出液が不溶化処理土に吸着する分配係 数も算出した (表-3 参照)。その結果, 水銀の不溶化処理 を行った地盤においては, 不溶化処理土からの溶出液が試 薬やガレキ溶出液に比べて分配係数が高い值となり, 土一 の吸着性が高いことを確認した。すなわち, 不溶化処理土 から再溶出した水銀は, 不溶化処理土に吸着しや寸い状態 である。一方, ふっ素は不溶化処理土と試薬で土への吸着 性に大きな違いは確認できなかった。

\section{3 数值解析結果}

図-21 から図-24 に不溶化処理の有無および不溶化処理 地盤から不溶化なし地盤に有害物質が移動した場合にお ける水銀とふつ素の 100 年後の濃度分布状況を示す。不溶 化処理なしの図は, 容易に判別できるように対数目盛とし ている。その結果, 100 年後に基準值 (水銀 : $0.0005 \mathrm{mg} / \mathrm{L}$, ふっ素 : $0.8 \mathrm{mg} / \mathrm{L}$ ）以下となる移動距離は, 不溶化なし地盤

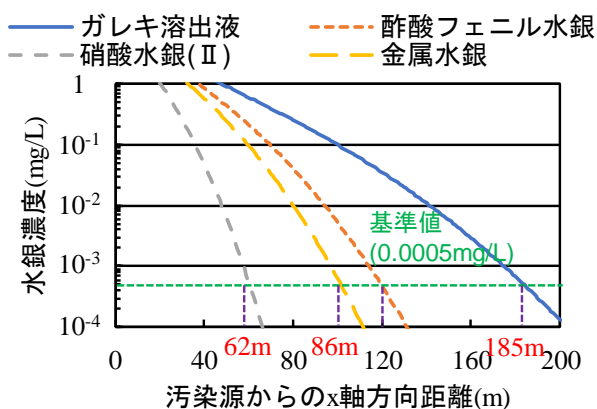

図-21 100 年後の濃度分布解析結果 (水銀, 不溶化処理なし)

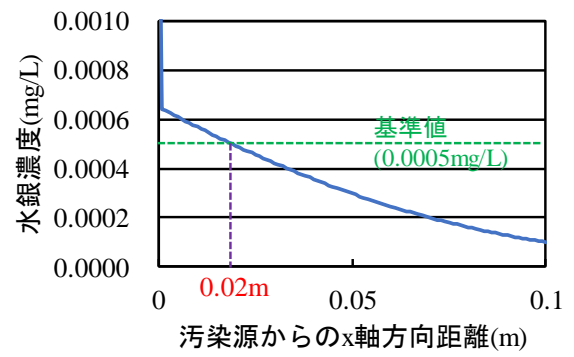

図-22 100 年後の濃度分布解析結果 (水銀, 不溶化処理あり)

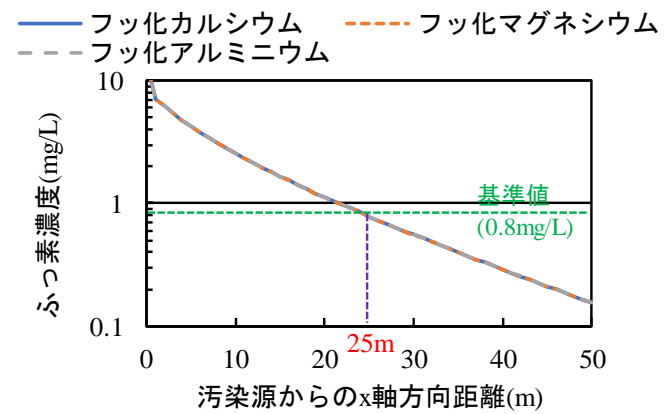

図-23 100 年後の濃度分布解析結果 (ふっ素，不溶化処理なし)

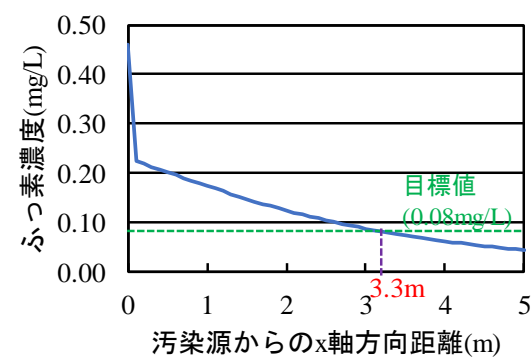

図-24 100 年後の濃度分布解析結果 (ふつ素, 不溶化処理あり)

において硝酸水銀( II )で $62 \mathrm{~m}$ 地点，ガレキ溶出液で $185 \mathrm{~m}$ 地点となったが, 不溶化処理を行うことによって $0.02 \mathrm{~m}$ 地 点となった。一方，ふっ素については，各種試薬で実施し た吸着試験から算出した分配係数がほぼ同一であること から解析結果にほとんど変化がなく，不溶化なし地盤にお いて 100 年後に $25 \mathrm{~m}$ 地点で基準適合となった。不溶化処 理を行うことによって $3.3 \mathrm{~m}$ 地点で目標值以下となった。

不溶化処理地盤から不溶化なし地盤へ污染物質が移動 した場合の結果を図-25 と図-26に示す。水銀とふっ素とも に不溶化処理地盤よりも長距離まで移動した。しかし, 100 年経過した場合でも両物質ともに $40 \mathrm{~m}$ 程度で $0 \mathrm{mg} / \mathrm{L}$ とな ったため, 不溶化なしの結果に比べると不溶化処理によっ て拡大する可能性は小さくなることが示された。 


\section{4 数値解析結果の考察}

数值解析では, 不溶化処理有無による水銀およびふっ素 の挙動の違いを把握した。その結果, 当サイトにおいては, 不溶化処理を行うことによって，100 年後の水銀ガレキ溶 出液の移動距離が $185 \mathrm{~m}$ 地点に対して $0.02 \mathrm{~m}$ 地点となった ことで $1 / 9,250$ 倍程度, ふっ素試薬の距離が $25 \mathrm{~m}$ 地点に対 して $3.3 \mathrm{~m}$ 地点となったことで $1 / 13$ 倍程度まで抑制でき た。さらに, 不溶化処理地盤から污染物質が再溶出し, 不 溶化なし地盤に移動した場合の挙動を解析した結果, 水銀 とふっ素ともに 100 年後には不溶化処理地盤と不溶化な し地盤の境界から $40 \mathrm{~m}$ 程度で $0 \mathrm{mg} / \mathrm{L}$ となった。

以上のことより，不溶化処理を行うことで污染濃度と地 盤の透水性が低下寸ることで地盤中の污染物質の移動距 離を抑制できた。さらに，水銀は再溶出した場合でも不溶 化処理土との再吸着により移動距離を低減できた。

\section{5. まとめ}

本研究で対象としたサイトにおいては, 不溶化処理によ り, 短期的には目標となる污染濃度までの低減が可能であ った。一方, 長期的には, 通水溶出試験の結果によって污 染物質の再溶出も懸念された。しかしながら, 不溶化処理 に伴う地盤の透水性低下および処理土が污染物質を再吸 着する性状を本研究で提示した室内試験で評価し, それら の結果を考慮した数值解析を行うことで, 敷地境界外への 污染物質の流出防止の有無を評価可能と考えた。その結果， 本研究で対象としたサイトでは流出しないと評価された。

原位置不溶化処理は，掘削除去および場外搬出などより も比較的低コストで低環境負荷の技術である。本研究のよ うに定量的評価手法により污染物質の再溶出および地盤 内挙動に関するリスク管理を行うことができれば当技術 をより広く展開できると考えられる。

\section{参 考 文 献}

1) 環境省 : 平成18年度 土壤污染対策法の施行状況及び土壌污染 調査・対策事例等に関寸る調査結果, pp.1-62, 2007.

2) 橋本洋平，和田信一郎，矢内純太，村上政治，牧野知之 : 土 壌污染の原位置浄化対策の現状と今後, 日本土壌肥料学䧱誌, 86(3), pp.246-251, 2015.

3）地盤工学会 : 土袞・地下水污染の調査 - 予測 - 対策, 地盤工 学会, pp.168-177, 2003

4）上岡誠一，粕谷衛：土壌に含有する6価クロムのセメント系固 化材による原位置不溶化処理に関する基礎研究, 土木学会論 文集, No.664, VII-17, pp.43-54,2000。

5) 西田憲司，三浦俊彦，日笠山徹巳，平井恭正，土光政伸，森 田一太，大澤誠司 : 微細な酸化鉄粒子の地盤注入による污染 拡散防止手法の実証試験, 土木学会第68回年次学術講演会, pp.145-146, 2013

6) 王寧, 笹木弘, 加藤和夫, 片岡昌裕, 佐藤宏士 : 重金属不溶 化処理土壤の $\mathrm{pH}$ 安定性の相対的評価方法について-硫酸添加 溶出試験法・消石灰添加溶出試験法-, 第14回地下水土㙥污染 とその防止対策に関する研究集会講演集, S5-10,pp.568-572, 2008.

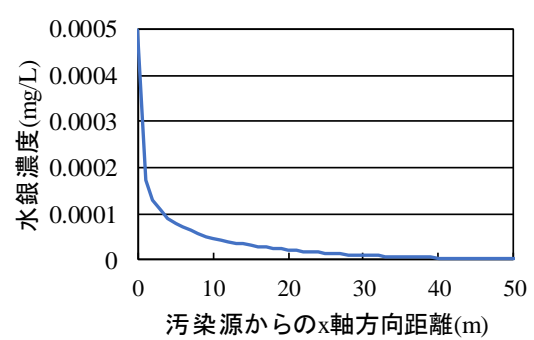

図-25 100 年後の濃度分布解析結果

（水銀，不溶化処理地盤から不溶化なし地盤への移動）

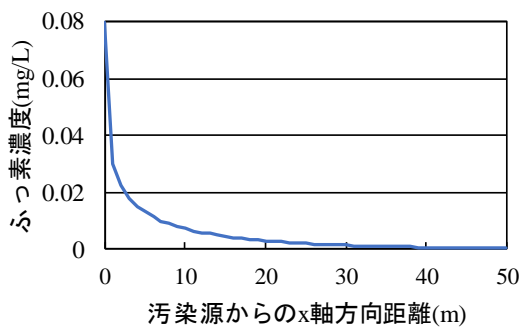

図-26 100 年後の濃度分布解析結果

（ふつ素，不溶化処理地盤から不溶化なし地盤への移動）

7) 佐藤毅, 川端淳一, 看倉宏史 : 不溶化処理土からの重金属溶 出挙動評価, 土木学会第72回年次学術講演会, pp.575-576, 2017.

8) 小嶋芳行，大島史也，松山祐介，守谷政彦：酸化マグネシウ ムによる重金属イオンの不溶化機構の解明, Journal of the Society of Inorganic Materials, Japan, 19(356), pp.15-22, 2012.

9) 小口深志 : 重金属污染土の原位置不溶化処理に関する研究, 資源処理技術, Vol.41, No.3, pp.107-113, 1994

10）大山将，奥村正孝，保賀康史，西村良平 : 酸化マグネシウム 系材料による固化・不溶化処理技術, 地盤工学会誌, Vol.57, No.7, pp.20-23, 2009.

11) 高橋史武, 坂井仁, 島岡隆行, 中居直人, 北村洋樹 : 電気炉 スラグ含有フッ素のアパタイト処理による不溶化メカニズム の検討，土木学会論文集 G, Vol.72, No.7, III_pp.351-359, 2016.

12) 亀井健史, 蓬莱秀人 : 高炉セメント B 種による半水石膏のフ ッ素不溶化技術の開発, 地盤工学ジャーナル, Vol.4, No.1, pp.91-98, 2009.

13） 三浦俊彦，久保博，藤井研介 : 水銀污染土と砒素污染土の不 溶化処理の検討事例, 第39回地盤工学研究発表会, pp.22192220, 2004.

14）福武健一，三浦俊彦，日野良太，亀田健太郎，日笠山徹巳： ふつ素污染土壌に対する不溶化処理の事例, 土木学会第74回 年次学術講演会, pp.VIII-76, 2019.

15) 酒井伸一，水谷聡，高月紘 : 溶出試験の基本的考え方, 廃棄 物学会誌, Vol.7, No.5, pp.383-393, 1996.

16) 眞鍋磨弥，肴倉宏史，鈴木隆央，勝見武，乾徹，高井敦史 : 津波堆積物を想定した河川及び海底堆積物の拡散溶出特性の 評価, 第12回地盤環境工学シンポジウム, pp.431-438, 2018

17) 貫上佳則, 毛利光男, 加瀬隆雄 : 改良 BCR 逐次抽出法による 污染土壌中の重金属の形態と溶出特性の評価, 土木学会論文 集 G, Vol.64, No.4, pp.304-313, 2008.

18）三浦俊彦，柴田健司，日笠山徹巳：ふつ素污染土壌のセメン 卜を用いた不溶化事例, 第52 回地盤工学研究発表会, pp.20212022, 2017

19) Domenico, P.A., : An Analytical Model for Multidimensional Transport of a Decaying Contaminant Species, Journal of Hydrology, 91, pp.49-58, 1987

20) 地盤工学会 : はじめて学ぶ土壌・地下水污染, 地盤工学会, pp.130-132, 2010

21）環境省：土垬污染対策法に基づく調査及び措置に関するガイ ドライン（改訂第3版）Appendix-1, 2019. 


\title{
A STUDY ON LONG - TERM STABILITY OF CONTAMINATED SOILS WITH MERCURY AND FLUORINE TREATED BY IN - SITU INSOLUBILIZATION METHOD
}

\author{
Ryota HINO ${ }^{1}$, Toshihiko MIURA ${ }^{1}$, Kenichi FUKUTAKE ${ }^{1}$, Kenji NISHIDA $^{1}$, Tomotaka MORISHITA ${ }^{1}$, \\ Tetsumi HIGASAYAMA ${ }^{1}$ and Nobuyuki EGUSA ${ }^{2}$
}

1 Obayashi Corporation

2 Wakayama University

\begin{abstract}
This study evaluated the long-term stability soil contaminated with mercury and fluorine treated by in-situ insolubilization treatment. It is necessary to (1) quantitatively evaluate the elution suppression effect of the in-situ stabilization method and (2) understand the behavior of re-eluted contaminants. The former was evaluated by laboratory tests using insolubilized contaminated soil taken at an actual remediation project site. The latter was examined by numerical analysis simulating the behaviour of re-eluted contaminants. Based on the tests and analysis, it was expected that the elution from insolubilized mercury-contaminated soil would be sustained below environmental standard for 130 years and that from insolubilized fluorine-contaminated soil for more than 1,800 years. In the case of mercury, its dispersion would be limited less than $0.02 \mathrm{~m}$ even after 100 years, due to insolubization which changed the chemical form of contaminants and decrease the water permeability of soil. It was concluded that it is possible to quantitatively evaluate the long-term elution suppression effect of in-situ insolubilization treatment.
\end{abstract}

Key words: In-situ Insolubilization Method, Laboratory Test, Numerical Analysis, Mercury, Fluorine 